\section{The difference of anti-inflammatory effect of brown algae extract panida sp and sargassum sp that is derived from Punaga Beach, South Sulawesi}

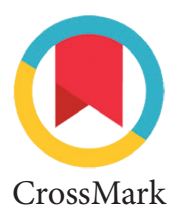

\author{
Asmawati, ${ }^{*}$ Rafikah Hasyim, Andi IA. Lianingsih, Dwi F. Ariani
}

\title{
Abstract
}

Objective: This study was to evaluate the difference of antiinflammatory effect of brown algae extract padina sp. and sargassum sp. derived from Punaga Beach, South Sulawesi against mice. The Punaga Village that is located in South Sulawesi is an area where most people work as seaweed farmer and in the cultivation of seaweed. This is why researcher found it interesting to use natural sources as an alternative of herbal medicine especially as an anti-inflammatory. Material and Methods: Twenty male mice used as sample in this study, weighing 14-35 g and divided into four groups. Thirty minutes after injection of test material, a dose of $0.5 \mathrm{ml}$ peptone $1 \%$ was injected into mice leg. The assessment of mice leg was done using plethysmometer on the first hour until fourth hour after injection of peptone $1 \%$. Data analysis used T-test to find out the difference of anti-inflammatory effect of brown algae extract padina sp. and sargassum sp.

Results: Showed that brown algae extract padina sp. has $p<0.05$ and brown algae extract sargassum sp. has $p<0.05$, which means that there are anti-inflammatory effect found in both test materials. Conclusion: It is found that brown algae extract padina sp. has longer anti=inflammatory effect half time more than brown algae extract sargassum sp.
Department of Oral Biology, Faculty of Dentistry, University of Hasanuddin, Makassar, Indonesia
*Correspondence to: Asmawati, Department of Oral Biology, Faculty of Dentistry, University of Hasanuddin, Makassar, Indonesia asmaamin68@yahoo.com

Received: 16 June 2016 Revised: 15 August 2016 Accepted: 17 August 2016 Available Online: 31 August 2016

Keywords: Anti-inflammatory, Brown algae extract padina sp, Brown algae extract sargassum sp, Inflammatory Cite this Article: Asmawati, Hasyim R, lianingsih AIA, Ariani DF. 2016. The difference of anti-inflammatory effect of brown algae extract panida sp and sargassum sp that is derived from Punaga Beach, South Sulawesi. Journal of Dentomaxillofacial Science 1(2): 109-112. D0l:10.15562/ jdmfs.v1i2.8

\section{Introduction}

United Nations Convention on the Law of The Sea (UNCLOS) in 1982 reported that the vast waters of Indonesia is 5.8 million $\mathrm{km}^{2}$ and included $27.2 \%$ of all species of flora and fauna in the world. Seaweed is one of the biological resources that are abundant in the waters of Indonesia, which is about $8.6 \%$ of the total sea life. ${ }^{1}$ Today, more than 1000 species of seaweed have been reported and has been included as new species. ${ }^{2}$

Nursid et al. ${ }^{3}$ stated that seaweed is divided into three major groups based on their chemical composition, namely green algae (chlorophyta), red algae (rhodophyta) and brown algae (phaeophyta).

The phaeophyta is a brown seaweed or brown algae that contains a wide range of bioactive compounds, which can be utilized as a nutraceutical material. ${ }^{3}$ Brown seaweed has many potential: an anticancer ingredient, anti-oxidant, anti-thrombotic, anti-coagulant, anti-proliferative, anti-virus, anti-obesity and anti-inflammatory. ${ }^{1,4}$ Several studies have shown that brown seaweed has potential as an anti-inflammatory because it contains sulfate polysaccharides, polyunsaturated fatty acid (PUFA) and fucoxanthin. ${ }^{4,5}$

Inflammatory response can occur due to infection, tissue damage or disruption of immune response. The process is always followed by the release of inflammatory mediators "prostaglandin". An increase of prostaglandins in the tissues will cause a sense of pain. ${ }^{6}$ Inflammation with pain can occur due to several factors such as infection, trauma and postoperative. If there is inflammation accompanied by pain caused by the infection, then the treatment can be done with the administration of antibiotics and anti-inflammatory supplements. If the problems arise purely from the inflammatory reaction, then it indicates for the administration of anti-inflammatory supplements. ${ }^{7}$

South Sulawesi waters with an approximate length of $2.500 \mathrm{~km}$ coastal line can be utilized for the cultivation of seaweed. ${ }^{8}$ This holds the potential for both biological and non-biological marine resources to be promising. ${ }^{9}$ Takalar Regency is one area that is very appropriate for seaweed cultivation because the condition of the land is flat along the west coast of the Makassar Strait to the south coast of the Flores Sea. The Punaga village is a region that is surrounded by beaches so most people in that area cultivate seaweed. ${ }^{8}$ This is what makes the cultivation of seaweed that is abundant in Takalar Regency so it could potentially be an alternative herbal treatment in particular anti-inflammatory drugs. 


\section{Material and Methods}

This laboratory experimental study used brown algae padina sp. and sargassum sp., which were taken from Punaga beach, Takalar. This study has been approved by Ethical Committee Faculty of Medicine Hasanuddin University, Makassar, Indonesia. This experiment was carried out in accordance with the guidelines laid down by National Institute of Health (NIH) in the USA regarding the care and use of animals for experimental procedures and in accordance with local laws and regulations. The algae are cleaned with seawater first and then cleaned using fresh water. After cleaning, the samples were dried for three days. The samples were extracted by maceration method using methanol and three days later, the separated samples with methanol solvent were extracted using a vacuum rotary evaporator. The extraction procedure was carried out in Laboratory of Phytochemistry, Faculty of Pharmacy Hasanuddin University, Makassar, Indonesia.

This study used 20 male mice with criteria, such as weight in the range of $14-35 \mathrm{~g}$ and can be adapted for a week in the laboratory. The mice were borrowed from a special research institution and returned alive after research. After the test

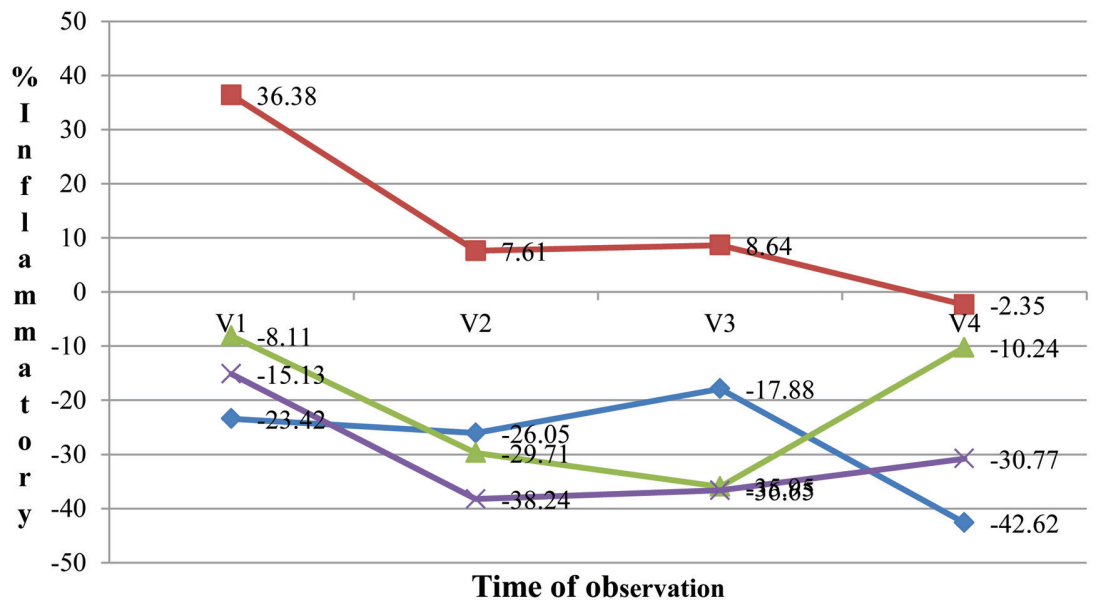

$\multimap \mathrm{NaCMC} \leftrightharpoons$ Natrium Diclofenac $\longrightarrow$ Padina sp. extract $\longleftarrow$ Sargassum sp. extract

Figure 1 Graph of percentage inflammation in mice paw materials and test animals were ready, we then started test procedures with anti-inflammatory effect. Testing was conducted at the Laboratory of Biopharmaceutical Hasanuddin University. The Animals were divided into four groups with 5 mice in each group. First group as positive control were treated with diclofenac sodium solution with a dose of 12:35 mg/35 g b.w. orally, using a cannula. Second group as negative control group was treated with NaCMC solution. The third group was treated with padina sp. extract with a dose of $7 \mathrm{mg} / 35 \mathrm{~g}$ b.w. orally. The fourth group was treated with sargassum sp. extract at a dose of $6.125 \mathrm{mg} / 35 \mathrm{~g}$ b.w. orally. After 30 minutes of administration of four test materials, the material injected induced inflammation that is peptone $1 \%$ $0.05 \mathrm{ml}$ in the left foot subplantar of mice using insulin syringe. Shortly after induction of the inflammation, an increase in the volume of mice feet occurs. Measurement of mice foot volume was done using plethysmometer at 1-4 hours after injecting peptone $1 \%$.

Measurement result of inflammation volume of each leg of mice was then processed into a percentage formula of inflammation (Vt-Vo)/Vo x 100\%, Vt: Foot volume after injection inducer of inflammation, Vo: Foot volume before injection inducer of inflammation.

\section{Results}

From the study that has been done, mean and standard deviation of percentage measurement of inflammation in a time of 1-4 hours after induction of inflammation as seen in the followingtable 1 and figure 1 .

Inflammatory percentage measurement data processing was done using SPSS 22. From repeated ANOVA test analysis a significant increase in the percentage of inflammation from 1 to 4 hours after injection of inflammation inducer in both the test group padina sp. and sargassum $\mathrm{sp} .(\mathrm{p}<0.05)$. t-test analysis showed a difference between groups of anti-inflammatory effects padina sp. and sargassum sp.

Table 1 Inflammatory percentage

Time

$\%$ mice paw inflammatory

\begin{tabular}{lcccc}
\cline { 2 - 4 } Material & $\mathbf{V}_{\mathbf{1}}$ & $\mathbf{V}_{\mathbf{2}}$ & $\mathbf{V}_{\mathbf{3}}$ & $\mathbf{V}_{\mathbf{4}}$ \\
\hline Natrium Diclofenac & $36.39 \pm 92.13$ & $7.61 \pm 66.74$ & $8.63 \pm 70.00$ & $-2.35 \pm 34.79$ \\
NaCMC & $-23.42 \pm 12.71$ & $-26.05 \pm 10.11$ & $-17.88 \pm 25.64$ & $-42.62 \pm 17.40$ \\
Padina sp. extract & $-8.11 \pm 2.53$ & $-29.71 \pm 3.36$ & $-35.95 \pm 9.83$ & $-10.24 \pm 19.81$ \\
Sargassum sp. extract & $-15.13 \pm 23.02$ & $-38.24 \pm 12.55$ & $-36.65 \pm 18.37$ & $-30.77 \pm 12.18$ \\
\hline
\end{tabular}




\section{Discussion}

In this study, brown algae padina sp. and sargassum sp were used because they have a good effect in particular as anti-inflammatory biological activity. According to Jaswir et al. ${ }^{10}$ seaweed contains a rich bioactive potential to be used as medicine. In particular, brown algae seaweed can be used as anti-inflammatory because it contains sulfate polysaccharides (fucoidans) which plays a role in inhibiting inflammation process. In a study conducted by Hong et al. ${ }^{11}$ who examined the seaweed sargassum swartzii (phaeophyta) and ulva reticulata (chlo-rophyta) as an antiinflammatory agent by using experimental animals. The method used three types of induced edema in the feet of animals, peritonitis method and antiinflammatory chronic effects method. The result of the study showed that sargas-sum swartzii and ulva reticulata have anti-inflammatory effects without serious toxic effects even at high doses, thereby strengthening allegations of the healthcare industry and medical community that seaweed can be used for inflammatory symptom.

This study used sample seeker method by maceration as maceration is the process of extraction methods and the tools are simple. Selection with maceration also aimed to avoid decomposition of the active substances contained in the sample by heating. Methanol is used as solvent in this maceration because it can dissolve almost all organic compounds in marine invertebrates, both polar and non-polar and methanol has a low boiling point $\left(67.5^{\circ} \mathrm{C}\right)$ so it is easy to vaporized. ${ }^{12}$

The study showed a significant change in the percentage of inflammation between 1 hour and 4 hours after injection induced inflammation. The change in value caused by anti-inflammatory properties exist in padina sp. and sargassum sp. table 1 showed that in test material padina $\mathrm{sp}$ there was a decrease inflammation volume in first hour up to three hours. Similarly to the group sargassum sp which had decrease in inflammation volume in the first hour up to two hours. This phase is referred to as the initial phase, which is the phase of inflam-mtory inhibition..$^{13}$ On the third to the fourth hour there are increase in inflammatory volume in mice feet for padina sp. The inflammation may be caused by the effects of brown algae padina sp. extract, which works in the body of mice as an antiinflammatory agent during the first 3 hours after the extract was administered orally. In the fourth hour, the effect of brown alga padina sp. extract as an anti-inflammatory agent did not work. This phase is referred to as accelerated phase, which is a phase of swelling followed by the release of pros-taglandin mediators, or a phase that occurs when the effect of the drug was not working. Therefore, the swelling/inflammation relapses with the release of inflammatory mediators without restriction of the anti-inflammatory content in drug and test material. ${ }^{13}$ While in the acceleration phase, the test material group sargassum sp. occurred faster in the second hour to third hour.

\section{Conclusion}

Brown algae padina sp. and sargassum sp. that is obtained from Punaga Beach, Takalar Regency can reduce inflammation volume in mice, thus can be used as an anti-inflammatory agent. On testing the anti-inflammatory effects, it was concluded that the brown alga padina sp. has a half-life as an anti-inflammatory agent that is much longer than the sargassum sp.

Further research is needed on the extract of brown algae padina sp. and sargassum sp. as anti-inflammatory agent using different doses to determine the comparative effectiveness of antiinflammation and the most effective dose as an anti-inflammatory agent.

\section{Acknowledgement}

The author would like to thank the farmers of brown algae in Punaga Village. Also thanks to Tanoto Foundation for the financial support.

\section{Conflict of Interest}

The authors report no conflict of interest

\section{References}

1. Suparmi, Sahri A. Recognize the potential of seaweed: Study of seaweed resource utilization of industrial and health aspects. Indonesia: Sultan Agung; 2008. p. 95-116.

2. Tampubolon A, Grevo S, Gerung, et al. Biodiversity of macro algae in the lagoon island districts pasige district Tagulandang Sitaro, Indonesia). J Coastal and Tropical Marine 2013;2: 35-43.

3. Nursid M, Wikanta T, Susilowati R. The antioxidant activity, cytotoxicity and the content of fucoxanthin extract brown seaweed from Binuangeun banten beach, Indonesia). JPB Ocean and Fishery 2013;8: 73-84.

4. Limantara L, Heriyanto. Optimization of the extraction process fucoxanthin brown seaweed padina australis HAUCK using polar organic solvents, Indonesia. Oceanic Science 2011;16: 86-94.

5. Jaswir I, Monsur HA. Review anti-inflammatory compounds of macro algae origin: a review. J Medicinal Plants Res 2011;5: 7146-7254.

6. Suniarti DF, Soekanto SA, Arif A. Farmacology of dentistry, Indonesia. Jakarta: Badan Penerbit Fakultas Kedokteran Universitas Indonesia; 2012. p. 19-20, 30-31.

7. Hargreaves K, Abbott PV. Drugs for pain management in dentistry. Aust Dent J Medications Supp 2005;50: 14-22.

8. Selistiawati, Idris APS. Factors that influence the pro 
duction of seaweed kappaphycus alvarezii (in the case of the village hall built Punaga Takalar brackish water, in Indonesia). J Vokasi 2011;7: 187-191.

9. Harifuddin, Aisyah, Budiman. Margin analysis and marketing efficiency seaweed in rural districts mandalle Pangkep, Indonesia. Jurnal Agribisnis 2011;10: $38-48$.

10. Jaswir I, Monsur HA. Anti-inflammatory compounds of macro algae origin: a review. J Medicinal Plants Res 2011;5: 7146-7154.

11. Hong DD, Hien HM, Anh HT. Studies on the analgesic and anti-inflammatory activities of sargassum swatzii (turner) C. agardh (phaeophyta) and ulva reticulata forsskal (chlorophyta) in experiment animal models. African J Biotechnol 2011;10: 2308-2314.

12. Handayani D, Deapati M, Marlina. Screening activity of some antibacterial from Painan beach, West Sumatra, Indonesia. JSTF 2009;14: 89-90.
13. Radhika D, Veerabahu C, Priya R. Anti-inflammatory activities of some seaweed collected from the gulf of mannar coast, tuticorin, south india. Int $\mathrm{J}$ Pharm Bio Sci 2013;4: 39-44.

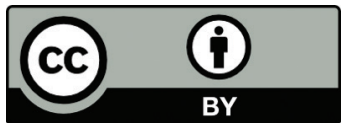

This work is licensed under a Creative Commons Attribution 